\title{
Implementation of Per Capita Education Funding in the Baltic States
}

\author{
Mikgelis Grīvinš \\ Advanced Social and Political Research Institute, \\ Faculty of Social Sciences, \\ University of Latvia \\ Lomonosova $1 \mathrm{~A}$ \\ Riga LV-1019, Latvia \\ E-mail: mikelis.grivins@lu.Iv
}

Abstract: Questions concerning education decentralization have been in the center of discussions for several decades now. The article supplements this discussion by analyzing how the decentralization of education policy is shaped at the national level and how its goals are elaborated at the local municipal level. To do this, the article analyzes per capita education funding policy in the Baltic states. I will proceed by analyzing interviews with persons responsible for education organization at the municipal level in Latvia. Estonia, Lithuania and Latvia have all introduced per capita funding in their education policy. Estonia introduced reforms in 1998, Lithuania in 2002, while Latvia in 2009. The three countries share many similarities in the policy implementation process and in problems they have to solve. Furthermore, all three countries with this policy have given greater voice in education planning to the local municipality and, as research attests, in all three states municipalities face similar problems in reform implementation. Latvian legislators, when implementing reforms, aimed to achieve two contradicting goals simultaneously: to improve pupils'achievement and to reduce education costs. Prior to the reform, the Ministry of Education and Science suggested that its success would depend on education planning-appointed local education experts assigned the task of guiding their county through the school network reorganization. This article illustrates similarities in the problems that the Baltic states have to face after the implementation of per capita funding. Additionally, it draws attention to the Latvian case-it analyzes the reasons why counties of Latvia have achieved differing results.

Keywords: decentralization, education funding, education planning, school network 


\section{Introduction}

The questions of education management and funding have always captured the interest of researchers. However, in the last decades it seems that these questions have drawn even greater attention. This is especially true of the states of the former Soviet Union - most of the countries which regained independence first sought ways to decentralize the highly centralized Soviet Union's education system (Heidmets et al., 2011). Yet, afterwards many of these countries had to figure out how to solve the problems created by the inherited school networkpolitical decisions, depopulation and the need to limit education expenditures.

This article contributes to the discussion concerning education decentralization and marketization and shows how education funding policy, intended to overcome the typical threats of decentralization, becomes one of the main generators of problems. Furthermore, in this article I underline how the main problems associated with decentralization emerge not only from policy itself, but from its unclear implementation guidelines. In order to illustrate the abovementioned factors I am analyzing education policy reforms in Latvia and compare them to similar reforms in the neighboring states, Estonia and Lithuania.

In 2009, Latvia introduced the reform called 'money follows the student' in the general education system. ${ }^{1}$ The official vision of the Ministry of Education and Science (hereafter referred to as MoES) was that the changes introduced by the reform in the funding structure of general education would lead to an increase in the education system's economic efficiency and to higher student achievements (MoES 2009, Ch. 5 and 6, pp. 13-15). Latvia was the last of the three Baltic states to introduce funding decentralization reforms. Estonia made its first efforts in 1994, but per capita funding was introduced only in the year 1998. Lithuania introduced its system called the "student's basket" in 2002. The three states and their policies have a lot in common both in terms of policy regulation and issues concerning the implementation.

Three years after the education funding reforms in Latvia were introduced, it is evident that results between counties differ significantly. There are differences in the number of schools that have been either closed or reorganized in various counties, there are significant differences between teacher salaries and

1 The changes in education funding were introduced by Regulation No. 837 of Latvia's Cabinet of Ministers (Ministry Regulations, 2009a). However the original Regulation was in force just for a few months and soon (in the same year, 2009) was changed to Regulation No. 1616 (Ministry Regulations, 2009b) which is more favourable to schools and planning districts. 
differences in resources that counties are allocated by the state, etc. (see Hazans, 2010). The education systems of some counties struggle to survive while in others they are thriving. Some counties seem to be introducing new ways of attracting students while others are struggling with legal issues. Meanwhile, the two other Baltic states have managed to identify the main problems, discuss them and have implemented new modifications to original policies. Although it is impossible to estimate whether improved policies have managed to solve all the problems, it is clear that the ground reasons for these problems are similar to the case of Latvia. The experience gained and conclusions arrived at in these states can be taken as a abundant source to formulate a better understanding of processes taking place in Latvia.

This article analyzes the reasons why the results of the reform are divergent in Latvia's counties. The article is based on interviews conducted from 2010 to 2012 with local education planners from several counties. Additionally, in order to gain a better understanding both the policy and its implementation process is compared to the other two Baltic states-Estonia and Lithuania. When starting to carry out interviews with the planners I was interested in finding out how they actually plan the education system. However, after the preliminary observations, further interviews concerned about finding out how planners interpret their position within the broader education system and how they interpret their actions within a county.

\section{Education policy in the Baltic states}

After regaining independence, all three Baltic states started with same decision to decentralize the education system - the role of the state in providing education was reduced, yet municipalities were given more rights in education organization. As a result, the ownership of the majority of public schools in Estonia, Latvia and Lithuania was transferred to municipalities. After these reforms the general situation has not changed and only a small proportion of all schools are owned by the state and by private school keepers. Both then and now teacher salaries have been and are being funded by the state in all the three countries. However, before the decentralization reform the amount of sums granted for teacher salaries was calculated according to the programs that schools offer to their pupils.

Future development of such funding structure reveals problems that national education systems will have to solve in the next decades. First of all- 
municipalities have been given the right to found schools in order to start expanding their school network, and by doing so, they quickly raise national education expenditures. Meanwhile low birth rates and emigration have reduced the number of pupils. This has led to an increasingly expensive education system and to a need to rethink the education funding system. So these factors have naturally led to a search for new funding structures. The three countries have found their solution in per capita funding. However, because of uncontrolled school closure none of the states have applied the so-called 'voucher system' - all chose a more safe path and directed per capita grant to the local municipalities. The need to take into account teacher salary limitations forced the local municipalities to think more rationally.

Yet before analyzing teacher salary distribution I should note that in three Baltic states statutory teacher salary, compared to the OECD average, is low. Hazans reports that in the school year 2009/10 the average statutory salary for Latvia's teachers was 60 per cent of GDP per capita (Hazans, 2010). Eurydice data shows that in the school year 2011/12 both the minimum and the maximum statutory salary were lower than GDP per capita in all the three states. In Lithuania and Latvia, teacher statutory salary is lower than in Estonia. However while in Estonia the average actual teacher salary is in the limits of the statutory salary (closer to its upper limit), in Latvia and Lithuania the average actual salary is well above the statutory (Eurydice, 2012). This can be explained mainly with fact that in both countries there are additional allowances that are used to index original salaries and a teacher can engage in additional activities that increases his salary.

The following chapters compare per capita education funding policies in the Baltic states and illustrate the main problems that are associated with the implementation of these policies. To analyze education policy in the Baltic states I am addressing three questions: how the general education is funded; what were the per capita funding policy goals; what is the role of municipality.

\subsection{Funding sources}

Schools in the three countries are mainly owned by the state and the local municipalities. Up to the year 2002, the schools of general education in Lithuania were financed from municipal budgets and the size of funding varied from municipality to municipality. School employees' salary levels, however, were established by the central government (Kaminskas, 2010). The number of salaries was calculated according to the amount of programs a school offered. It means that the total amount per school was based on calculations about how 
many teachers a school needs to employ to successfully provide its school programs. However, in the year 2002, Lithuania introduced education funding policy referred to as "student's basket", which basically meant that all stateassigned funding grants will be calculated per capita and with this funding the state compels the local municipality to fulfill obligations to further distribute this fund. The amount of granting per capita is indexed and thereby differs from pupil to pupil. In Lithuania, the policy takes into consideration school and class sizes, education level, special needs of students and the type of school. The use of the "student's basket" funds are regulated by the official policy and it can be used just in a way as it was adopted by Lithuania's MoES. This means that it can be used for "teaching and non-teaching staff remuneration, acquiring textbooks and other teaching aids, teacher in-service training, school administration, school library maintenance, and social and psychological assistance." (MoEs, Ch. 11). However, the municipality is responsible for education environment, which means that it covers all the expenses that are connected to a school's building maintenance, communal expenses, non-educational expenses, etc.

In Estonia, general education schools are mainly municipality-owned. As in the other Baltic states, a school receives funding from the state and from the owner. The share of expenses that each of the abovementioned stakeholders should fund has changed during last two decades and these changes illustrate the education system's ability to exist under per capita funding. As already mentioned, the first efforts to introduce per capita funding were made in 1994. However, the operational formula that reached its objectives was introduced as late as in 1998. This formula originally included several indices according to the territories' level of urbanization and population (special indices were tailored for the Estonian islands).

Furthermore, the amount of funding was indexed by several additional factors. In 2008, new formulae were introduced. The main amendment was that more attention was paid to the class size in lower grades. These changes were intended to support small rural schools and, as such, demonstrate the important discussion concerning the optimal class size and the need to offer alternatives for smaller schools. However, a secondary result of these changes is that the grant system is moving away from its genuine idea-per capita funding.

Originally, a grant allocated money for teachers' salaries and textbooks. Yet over the course of time several new tasks were assigned to granting - additional funds were added to the original amount of funding in order to cover some extracurricular activities, workbooks, capital expenditure, etc. In addition, municipalities received funds to provide free lunch for the first- to ninth-grade 
pupils. At the same time the owner of the school covers operating expensesmanagement costs, non-teaching staff salaries, additional teaching materials.

Latvia was the last of the Baltic countries to introduce per capita funding. Also, as in the other two Baltic countries, in Latvia the education expenses have been divided between the state and the municipality. The state uses per capita calculated targeted grants to cover teacher salaries and textbooks. Additionally, the state funds free meals for first-grade pupils. The state does not offer direct funds for the non-teaching staff. However, in order to promote a more efficient education planning, the non-teaching staff's salaries are included as a percentage in teacher salary grant. Therefore, every school can use up to 15 per cent of the total amount for hiring non-teaching staff. All other expenses, mainly associated with school maintenance, are covered by the school's owner.

Teacher salary grant has additional indices that are meant to promote equity when addressing different needs. Latvia's policy draws attention to education level, the special needs of the pupils, and pupil density in the local municipality. In addition, a special index is used for pupils in state gymnasia.

We can observe that the three states have chosen the same model of teacher salary funding. However, every country has used different components that will be taken into account when calculating the total amount of funding and how this funding can be used. Additionally, differences can be observed in what a given state has decided to fund. Although there are differences in reform goals that will be discussed below in further detail, I would like to suggest that the main goals are somewhat similar. Furthermore, the main issues after implementing per capita funding are the same. So the differences in funding should be articulated in order to explain the differences of interpretation in different countries as to what is considered free education.

\subsection{Reform goals}

As already mentioned there are some differences between the Baltic states as to how per capita funding is interpreted and how the reform goals are stated. However, when thinking about the reasons to introduce per capita funding, it is important to remember that in all post-Soviet states the inherited education system became too expensive. So it is more valid to state that in most cases the post-Soviet states did not have a real choice.

Estonia was the first of the three states to implement per capita education funding. The main reasons were to rationalize education network and to promote school competition. It means that it was expected that smaller funding for 
teacher salaries would force the closing of some schools. However, the need to close some schools would make all schools to operate more efficiently. The reforms of 2008 and modifications of the original per capita funding show that new goals are set for the policy (Alonso \& Sanchez, 2011, p. 281). Original per capita funding formula turned out incapable of solving what could be called the small school issue (a problem faced by all the three states).

Reforms in Latvia's education system were backed with similar arguments as in Estonia. Representatives from Latvia's MoES argued that there is a need to rationalize a school network that has become expensive and inefficient (MoES, 2009). As in Estonia, it was argued that per capita funding will promote competition. Additionally it was suggested that more direct allocation of funds would improve the quality of teaching.

Only some years after the original policy was introduced, Latvia's Minister of Education suggested that the country's education funding policy has to create more possibilities for smaller schools in rural areas (similar claims forced Estonia's policymakers to introduce funding reforms in 2008). Although policy modifications have not yet been introduced, discussions suggest that the considered solution is not associated with implementing new indices in per capita funding formula (as it is in Estonia), but is searched for in a possibility to assign new functions to small schools. Namely, it is considered how to allow smaller schools attract more funding.

A different situation can be observed in Lithuania where the same per capita funding policy is associated with a greater number of objectives. Lithuania's policy has the same targets as the other two Baltic states: to optimize the school network and to improve education competition. However, Lithuania's policymakers have included some additional factors too: reforms should promote equity, school autonomy, accountability, transparency and quality, etc. (Alonso \& Sanchez, 2011, p. 281; Shukauskaite, 2007)

Although the states propose a wide range of factors to back up per capita funding, it is clear that this policy was mainly implemented because of the need to rationalize the system that threatened or already had started to consume too many resources. Fighting with the municipalities which are unwilling to execute network optimization as intended is the next factor that influences the policy. The third factor to take into consideration is the need to search for ways to give additional opportunities for small schools. Additional policy modifications to save small schools and parent protests (see Levačić, 2011; Herczyński, 2011) show that none of the states are ready to face uncontrolled per capita funding and the situation needs some additional regulations. 


\subsection{The role of municipality}

As was mentioned, the situation in the Baltic states' education network needed some additional regulation. However none of the states were ready to introduce channel per capita funding directly to school and by doing so promote totally uncontrolled competition (the so-called 'voucher system'). Although one can speculate why the state did not choose such a way for the education policy, it is evident that with this decision new tasks for and new meanings of municipalities had emerged. As a consequence of this legislation, all three states simulated the importance of local municipalities in education planning. First of all, as was mentioned, a part of education expenses in all the states is funded by owner. In the Baltic states only a small fraction of schools belong to the state or are privately owned, while the vast majority is owned by local municipalities. After reforms, the municipalities were obliged to distribute targeted grant for teachers' salaries. It means that with these reforms, a municipality has been given a chance to operate with funding from two sources - from its own and the state's. In these countries, the local municipality is an institution that is built between state funding and the school. Its main purpose is to remove bias that could emerge from uncontrolled competition. This means that per capita fund is first transferred to a municipality which later on negotiates in regard of funding available for every school. However, this situation has created some new problems in education planning.

In Lithuania, municipalities have had the right to re-allocate a certain amount of funding among their schools. In 2002, this was 15 per cent of the total funding. In 2003 and 2004 the amount fell to ten per cent. From the year 2005 up to now a municipality can re-allocate five per cent of the total "student's basket" funds. With every school closure, the municipality faces protests of the local inhabitants and this is the reason why the local municipalities are not eager to close down schools. Fund allocation can be used to prolong the existence of unproductive schools. In 2004, Lithuania's MoES noticed that the municipalities are too slow to act with school closures and introduced obligations for them to adopt MoES' recommended consolidation strategies. Municipalities in this case acted against the aims of official policy. Furthermore, Jan Herczyński, after evaluating Lithuania's success in implementing per capita funding, has stated that the result of the policy could be described not as a competition between the schools, but as a competition between the municipalities (Herczyński, 2011).

In Estonia, local municipalities negotiate with schools about their budget. Municipalities are also free to decide how to allocate funds that are calculated for its territory and can, furthermore, make several decisions that influence their 
need for teaching resources (for example, a municipality can apply for additional state funding) or direct a larger share of its own resources toward education (this option is used by municipalities in all three countries).

The last of the three Baltic states-Latvia-has given an important role to municipality, too. In Latvia, a municipality can decide how to allocate funds that are targeted for teachers' salaries. Furthermore, a municipality has a wide selection of different tools that allow shaping school network within the municipality. This means that the municipality can either decide to close an ineffective school or not. Also in Latvia, as in other municipalities in the Baltic area, decisions about a school closure face parent complaints. Because of these complaints education network planning is complicated and constantly has to struggle with parents' attempts to protect their interpretation of their children's interests.

The above-described situation shows that in none of the Baltic states the changing of the funding system has worked as it was intended. Although it has succeeded in reducing state funding, it still struggles to improve education efficiency. This is mainly because a municipality's inhabitants support to their own local schools. Yet in some way it is a result that indicates a necessity for a newer funding policy. From the beginning all the three states have contributed a lot into the reforms to make them successful under the governance of local municipalities. Even more so, the states have given municipalities tools for acting against state's funding policy. Municipalities act against the states' original intentions, yet they are acting in a way that could have been predicted.

\section{Reforms in Latvia}

In further chapters I will draw more attention to Latvia's case trying to cover all the main aspects to describe per capita funding policy. However, this chapter, together with previous comparison of the three Baltic states, is given in order to supplement case studies into the same issues carried out by Rosalind Levačić in Estonia (2011) and Jan Herczyński in Lithuania (2011).

Because of this prior legislation and political history, Latvia's education system, similarly to other post-Soviet states, is characterized by a high number of small schools and therefore a high amount of resources needed to sustain such a system. The fact that the funding structure needs reforming has been discussed for more than two decades (for example, Bokans, 1996) and had been at the center of fierce public and political debates for several parliamentary terms. 
Only ten years before reforms, in the school year 1998/1999, there were 1,111 public schools and 361,722 pupils in Latvia. The MoES report for the school year 2008/2009 (a year before the reform) shows that the number of schools has dropped to 982 (drop by 12\%). However the number of pupils has decreased much faster-there were only 249,446 pupils (drop by $31 \%$ ). Although statistics has shown the need to take some political measures, no one seemed to be willing to implement changes that are likely to generate public distrust. Therefore reforms have been initiated by external pressure-namely, the economic crisis and consequently the need to borrow internationally. During the loan discussions, the national leader party pushed for a reform in the education funding structure. The changes agreed upon stated that after the reform teacher salaries would be related to the amount of time spent on teaching, yet teacher salary funding would be calculated on the basis of the number of pupils (i.e. per capita funding). Such a decision allowed a significant decrease in the state's education funding. In addition, instead of calculating funding for individual schools it was to be calculated on the level of a county, to be distributed between schools according to the local education development plan. It means that although the state and MoES are involved in assigning funds to counties, these institutions are not directly involved in fund distribution. To achieve better results, municipalities were encouraged to close, unite or specialize schools that were not able to attract the number of pupils that would be needed to pay for teachers' salaries.

Reforms were intended as a fast way to restructure the education system. Competition between counties should have forced to eliminate quickly small ineffective schools in every planning district. With this action the schools of municipality would become economically more effective in a short time, and further competition would improve the overall education quality.

Latvia's geographical and municipal structure consists of 119 administrative divisions ${ }^{2}$. For every county there should be a responsible institution or official (a type of education board, frequently consisting of just one person, hereafter referred to as education planners or, simply, planners) which regulates the local education system and is responsible for fulfilling MoES requests. At least officially this is the person who should introduce the plan of how to improve the education system of the particular county. This does not preclude counties from

2 This calls for an additional comment: in parallel to introducing the education funding reform, another reform - the Administrative-Territorial Reform (ATR) - was approaching its completion. The ATR defined the new geographical and municipal structure for Latvia, consisting of 119 administrative divisions of which 110 are counties and 9 major cities instead of the old structure of 26 districts and 7 major cities. 
collaborating in education organizations. Most counties have indeed chosen to stay independent and organize their education system by themselves. However, some counties decided to join together in their planning activities. No matter which strategy a county chooses, the education funding is first allocated to the county and then a designated body can decide on its redistribution among schools. Therefore, it is the level at which one should search for causes for a municipality's success or failure.

Several arguments for the need for a reform were stated at the time of the inception of the reform, the bottom line being that small schools are ineffective (the argument drawn from PISA results (see Geske et al., 2010)); furthermore, they are expensive and often have problems with transparent resource distribution (MoES, 2009). As was shown before, the question of small schools in Latvia had to be revisited later on. Only this time it was asked how some of these small schools can be saved? As was mentioned, Lithuania and Estonia too struggle with the question of how to keep the balance and give more opportunities to some small schools.

Yet prior to the reforms, MoES speculated that by promoting larger schools, pupils in rural areas would receive better education opportunities, having access to higher quality education, as education institutions would be more competitive and would tend to specialize. Other arguments supporting the reform stated that funding would be distributed closer to the education institution so it would be more transparent and actually would be allocated according to the problems that need solving (MoEs, Ch. 5-6).

Although there had not been any real discussion about how to react to these reforms and what consequences should be expected, some counter arguments were heard. Among the most active commentators were teachers and school principals, representatives of the non-governmental sector and education experts. The main line of argumentation suggested that the reforms were indeed necessary, yet reformers should consider schools not only as institutions of teaching but as a functioning agent of small rural communities as well. The local school is commonly an important employer, it provides cultural and learning activities for both pupils and the local community, the school has properly equipped facilities, it unites the local intelligentsia (teachers) and is an important source of information distribution (BISS, 2011).

Three years after the reforms took place we can see that the situation cannot be described by arguments suggested neither by supporters nor critics. The idea of allowing a local municipality to redistribute state funding was meant to save from 
the uncontrolled closing of local schools and from such a perspective it seems only logical that the researchers supporting competition tend to criticize this policy (for example, Hazans, 2010). Yet the ability to solve problems of competition with controlled resource distribution can be questioned by other researchers, too.

In the school year 2011/12 (the third year after reforms were introduced) the number of schools have dropped to 839 (drop from the school year 1998/99 by $24 \%$ ). The number of pupils in the same school year have dropped to 218,442 (drop from the school year 1998/99 by 40\%). In the school year 2012/13 every pupil was followed by 740.52 lats (around 1,050 euros) (in the last years this sum has increased). In 2011 Latvia's government spent around 155 million lats (approximately 220 million euros) in total to cover the funding for teacher salaries (total expenditures for teacher salaries have been steadily decreasing in the last years). Although more than a hundred schools have been closed in the last years, the situation is still inconsistent in various counties (see Fig. 1). There are counties with huge schools, but for most counties, the average school size is significantly lower than that of the average national school.

Figure 1. The counties' average number of pupils and teachers per school compared to national average in Latvia in the school year 2011/12

ECounty's a verage amount of pupils per school compared to nationa lavera ge amount of pupils per school

-County's a vera ge amount of tea chers per school compared to na tional a vera ge a mount of tea chers perschool

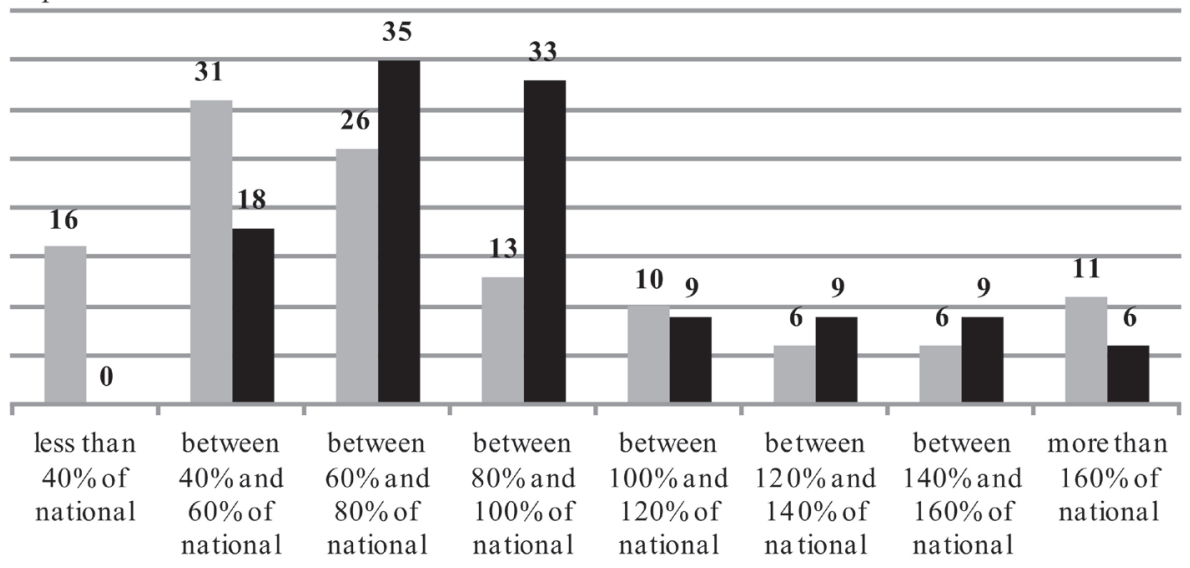

Source: My calculations based on the data of the Central Statistical Bureau, Ministry of Education of Latvia. The data is represented in total numbers and includes statistics on all 119 Latvia's counties. 
Additionally one can observe that the counties' average number of pupils per school compared to the national average is lower than the counties' average number of teachers per school compared to the national average. This means that in several counties, the actions have not resulted in improved education efficiency but most probably have just reduced the amount of teacher's work load and therefore salary.

The picture becomes even clearer when counties' funding per school is compared (see Fig. 2). If funding is compared to analyzing education funding per pupil, differences seems to be quite low. Since state funding is distributed according to the number of pupils, such similarity is not really a surprise and small differences can be explained merely by additional school funding from the municipalities. This just shows that some municipalities have been more generous to the local school system.

Figure 2. The counties' average funding per school and pupil compared to the national average

m County's average funding per school compared to national average funding per school

- County's average funding per pupil compared to national average funding per pupil

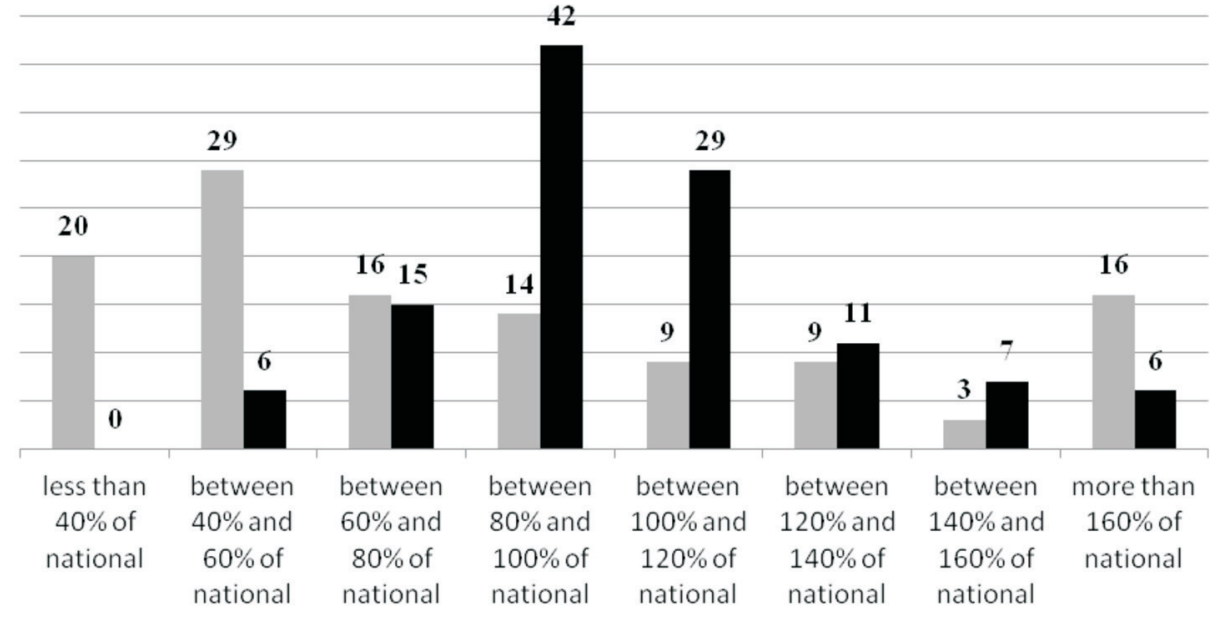

Source: My calculations based on the data gathered by the Ministry of Environmental Protection and Regional Development of Latvia, the counties' official budgets, as personal request from municipalities. The calculations are based on the total education budget in 2011. The data is shown in total numbers and represents 116 counties, with the exception of three counties because of the lack of official information.

However, larger differences can be noticed in analyzing the school system when comparing the average funding per schools. There are counties which 
have managed to improve the school system and have created an economically efficient school system, and there is the opposite extreme of counties with poor and very poor schools. Of course, data shown here should be approached with caution. To some extent it can be used to illustrate the differences that characterize various counties. Huge variations in factors that could be used to describe the local education system can be observed and although some variations can be explained in terms of geographical and demographic factors, most of it should be interpreted in a context of optimal education planning. Similar observations are reported both from Lithuania and Estonia.

\section{Methodological approach}

All three Baltic states showed that the original policy intentions were met only partly. Answering the question of how does a shift from the official policy take place can help to better understand the construction of the policy so that it would reach its goals. Latvia, as the last of the Baltic states to accept per capita funding, can be a valuable source for searching answers, because there are still original processes undergoing which can be observed. Additionally, as was shown before, there are broad similarities both in the problems the states are facing and in the solutions they are implementing.

To answer the question of how the implementation processes have influenced outcomes that do not match the original intentions, I addressed persons closest to the funding distribution in this case study - in Latvia's case, the persons in local municipalities who are responsible for education planning. During the research I conducted several interviews with the planners. These interviews covered such topics as optimal planning, the planners' interpretation of their work, and the unique characteristics describing the planners' county. Similarly, my questions did not just concern the respective counties' success or failure but the position of the education planner's job within the county, the planner's main duties and everyday tasks, challenges and problems, etc. So the interviews were not just dealing with the official policy, but with issues about how this policy had been accepted and acted upon in the context of the county. These interviews were meant to explain why a policy that has been implemented in a wide range of post-Soviet states had almost everywhere encountered the same problems.

During the fieldwork I conducted ten semi-structured in-depth interviews with education planners from various education planning districts. The interviews were carried out from autumn 2010 to January 2012. Here, the long time span 
should be regarded as an advantage rather than a disadvantage. After introducing the reforms there have been several further changes: some new counties have been established, some counties have decided to merge their planning or leave a joint education planning district, in some places the planner has been changed. As I will show in my analysis, the planner's experience and the logical, chronological development of the planning effort can influence the planning result greatly.

\section{Factors promoting the decreased system coupling}

Interviews with education planners analyzed from the perspective of their individual interpretation of dealing with a county's education planning reveal several factors that give valuable insight into how the differing outcomes in a county's education system are shaped. Overall we can observe that there are several ways how to distance from the official policy aims. Sources of these influences cover a wide range of agents and institutions and can be related to the various elements of planners' work. I will structure the explanation of these factors around three main elements: experience, relations and practice.

\subsection{Planning experience}

Local education planners give highly diverse descriptions about how they found themselves to be in the job position they were holding. Firstly, none of them had actively applied for this position - all had been recruited by their municipality. Furthermore they had been recruited from various positions and had various experiences.

There are four main places where the planners had been searched for. The first was addressing individuals who had been involved in education planning and organizing in former districts (i.e. former administrative territorial divisions of Latvia, generally much larger than counties). Every district had its education planning institution that consisted of both methodological committees and education planners. After the ATR (the Administrative-Territorial Reform) some newly formed counties turned to former experts with an offer to join their municipality. These experts had an experience in regional education planning, had contacts with other planners and in MoES. So by addressing this group the local authority hired both an expert and his already established contacts. While these employees were prepared to face the problems of a district education 
system, similarly to all other possible candidates they had not had experience in dealing with implementing the reform.

The second common place to search for planners were the local schools: the local authorities recruited for the job a more "active" teacher from a local school. The principles for teacher selection may have differed significantly and sometimes a teacher seemed to be promoted actively so that his school would receive certain benefits. Teachers are aware of the education situation and have well established relations within the local education system. However they lack experience in planning on a higher level. Furthermore, most of the teachers do not have contacts either in other municipalities or in MoES. So, in the beginning they are left alone with insufficient guidance and advice.

The third source of planners is the local authority itself. This seems to be done to maintain a potential position of power and to avoid difficulties that may emerge when searching and afterwards negotiating with a professional planner. Such a person does have local authority and is well aware of how a local municipality works both spatially and from the perspective of management. Additionally, he knows how decisions are made locally and is acquainted with hidden power structures. Still, he has little or no experience in education planning nor does he have outside contacts and may experience difficulties in finding a common ground to discuss problems with other involved agents. Even more-it seems that such a person is commonly used as a symbolic figure, while in reality there has been no real action to improve the local education system.

The fourth source for recruitment is "everyone else". Representatives of this group are usually without any real experience either in education, planning, or in the county's decision-making structures. It does not seem clear why these persons were addressed or what they have brought to this position. The most obvious guess would be that by bringing in such individuals the counties have preserved their internal power structures. This, however, does not mean that such planners are not actively working. They have problems with almost everything there is in education planning and their main everyday goal is to find help, to respond to official requirements, and to understand what is expected from them.

This shows that education planners are not a homogeneous group. To attribute this conclusion to a wider context one can suggest that various municipalities have various competencies. Although MoES and the state give guidelines to the municipalities, their ability to follow these guidelines varies. This is the conclusion that explains comments that Rosalind Levačić (2011) and Jan Herczyński (2011) make about Estonia and Lithuania—local municipalities deal with the issues they face and the implemented solutions are not always 
the most effective ones. I would supplement this comment by saying that the solutions correspond to the municipalities' experience. Yet one should remember that these differences discussed here as well as all other factors that will be described should be approached both as a source and as the explanation of other factors. So, it is clear that the experience that a municipality can access to or, as in Latvia's case planners who embody this experience, have been placed in this position not because of a single consideration, but because of a group of factors which have become important rather suddenly after the visible authority of education planning has been brought closer to the implementation level. Differences in experiences and in access to various resources generate differences in interpretation of what the planner should achieve and how he should achieve it. In the end such variations will put the reform into practice in a way that does not correspond to the original intentions.

\subsection{Sources of influence}

What has been already said brings us to the next perspective on valuating the planners' possible range of action. Here I would like to draw the readers' attention to the different sources that influence both the planner's decisions and his possibility to act. There are several influencing factors of which the most obvious is the one that lies on the basis of the reform - there is a limited number of pupils. Yet we can observe several less obvious sources which exert additional influence.

The first agent to mention, without whose approval nothing happens, is MoES. Although MoES is officially involved in introducing reforms and is highly interested in successful reform results, it is at the same time concerned with a whole range of other issues. For MoES, the local planner is like a space satellite which can report from a great distance and which can be used to convey messages to these distant places. So the planner is used to gather information, clarify rules, and, only among other duties, to plan the local education network. Additionally, MoES has not given the planners any real tools that could be used to achieve these goals. Some planners complain that MoES cannot even explain how to execute MoES's own official suggestions. At the same time, it still largely influences all the planners' decisions and holds them responsible for the outcomes. Although officially the planner is given authority to introduce an education system that would fit the county's needs, he still is kept on a short leash by MoES.

It is easy to observe the MoES influence in each Baltic country. All of them report several changes to the original reforms, so whenever the changes do not 
go as planned, MoES tries to create new control tools. This situation can be clearly observed in Lithuania's Act of 2004 which put a stronger pressure on the local municipalities to close down schools. Although the state renders its power in these matters to local municipalities, MoES holds strings to implement their education vision.

While MoES wields huge influence over what the planner can and must do, he officially remains employed by the local municipality. As an employee of municipality the planner does not have any real power and is subordinated to the local authority which, even though it has hired this person, may choose not to support the planner's vision for the education development. MoES cannot force the county to close its schools yet - it is as unpopular a decision on a county level as it is on the state level. The only difference is that on the county level the person who would allow a school to be closed is closer by and not as anonymous. As said above, in all three Baltic states school closure has been an unpopular decision and it has been opposed by parents expressing their dissatisfaction. So, from the political perspective there are also reasons why a municipality can decide not to act.

This brings us to the next source of influence-rural districts. In such a district, the school is very often one of the last actually functioning institutions, so the local community and district representatives are willing to keep it. Although the number of pupils in such a school is low, the local municipality has quite often made huge investments in the school infrastructure prior to the reforms. Closing the school at this point would mean losing all previous investments. Additionally, school is an institution that keeps youth from emigrating and guarantees the local community's future. Although this factor cannot be summarized under one influencing factor and is more associated with the overall spatial structure, because of real agents who can emerge to act in the interests of rural districts, it should be taken into account. This factor can be seen throughout the recent discussions in all three countries searching for solutions to how to save small rural schools from being closed. Before the matter was discussed in the official policy it has been already taken into account in the local municipalities' work.

Yet the greatest influence comes from the school itself. Although the planner is an agent who should be able to inspect and propose the closing of all educational institutions in a county and by doing so could be interpreted as being higher in the hierarchy than the school (as mentioned above), he nevertheless does not have any real instruments to go with his power position and fight off the school's influence.

This shows the variety of agents who are trying to gain power over the planner and by doing so push through favorable decisions. The planner is floating 
between all the sources and is required to collaborate with every one of them. So it seems that planning results can be often associated with the local support to reforms. A community's willingness to change can play a greater role than the planner's willingness to reform.

\subsection{Everyday practice}

The last factor I intend to describe here is what could be called everyday practice. This factor refers to the specific act in which the planner is forced to choose between several opportunities, accept the factors he cannot change, and get along with the community's interpretation of his position.

Here the planner's task to support all the information that MoES requires should be first mentioned. The planner is under constant pressure to gather and forward information that is needed for MoES's work. Although it is not the only task that planners have to carry out, it is enough of a workload, and if the planner is not involved or motivated to get involved in improving the local education system, then he is given an excuse not to do so. This means that the results will be largely depending on his willingness to achieve results.

Another factor is that education planning requires constant involvement and chronological long-term development. This seems obvious, yet it poses constant problems to some planners who either are working in a district where something has not been done before their employment or where they have decided not to do something. A planner's work should be a constant search for and use of these opportunities. So the long-term workers are at an advantage, since they have access to information and recognize the importance of applying for all sorts of benefits and grants. They have the experience to successfully apply for and stock teaching materials, equipment and other resources. It follows that the search for opportunities has to be one of the priorities for the planner.

Another important perspective in observing the planner's everyday practice is drawing attention to his relations with other involved agents. First of all, he is engaged in a constant battle over which schools will be closed and which will not. However, planners are complaining that they are dealing with problems that are far from the general education system planning, as they are forced to deal with angry teachers, parents, misbehaving pupils, etc. So whenever anyone disagrees with their direct authority they come to the planner. Therefore, especially in many smaller districts, the planner spends his time organizing communication and mediating conflicts. A huge amount of his time is spent on factors that are not associated with his direct responsibilities. These tasks could be interpreted as a result of closely situated learning. 
The variety of tasks that are associated with the planner's everyday work can be a reason to reconsider what the duties of a local education planner actually are. The planners have to communicate with MoES and complete all the officially outlined tasks. Yet other tasks also demand attention and it all can become a cause of conflict between the planner and the community. The planner's decision to direct his attention to one factor or another may significantly influence the kind of education planning he is carrying out. So the planners' interpretation of their duties is a factor that should be considered as decreasing the system's coupling.

This just proves that it can be wrong to analyze such reforms without a real context of actions around it. The local education system with all agents involved in it constructs its own needs and acceptable practices. To be able to implement a reform, either the planner has to be powerful enough to change such system habits or he should be able to participate in this system in a way that supports his own goals.

\section{Discussion}

Per capita education funding has introduced some problems in all three Baltic states. It can be speculated why it is so and I have tried to answer this question through a detailed analysis of one of these states.

The post-reform results achieved by various local municipalities should be perceived as a sum of several factors. I have shown here how various elements and influences tend to merge. Some of these differences have emerged because of state legislation, some stem from the planners' personal and professional traits, yet others can be associated with a specific county's situation. Furthermore, the influence of various agents will continue and deepen. So from this perspective it may seem that the only possibility is to return to centralization. This, however, is just one of the possible answers. A closer view of the factors I have described above would show that there are many possibilities to combine the intended decentralization and a given county's ability to decide about its schools and its path to attain the goals of the centralized education system. This means that probably the best possible solution would be further searching for ways of how to improve the policy. This then could be used to explain further policy changes in Lithuania and Estonia and to predict that there will be new changes in Latvia.

However, the question of how to make policy implementation fit the policy's targets does not seem as interesting as the possibility to look at this policy as 
if it was detached from the local municipalities' needs. This argument sounds as follows: most of the factors that I identified in my interviews with education planners could have been predicted before the actual legislation was elaborated. So, the question that emerges is - can we draw parallels between the goals of the legislators, MoES, and the education planners? During interviews, none of the planners seemed to acknowledge that they are not managing the centrally assigned tasks that are expected of them. They clearly illustrated how their actions are driven towards some system goals. So, this once more forces us to question whether the different levels of the education system are really linked together or even whether the planners of various counties act in accordance with the same goals. If such isolation and what I have described here as some of the functions of the education planner are a valid approach to the local education planning, it would be naïve to compare reform outcomes with MoES's intentions. This would uncover an interesting angle to use when analyzing the activities of local education planners: they are something of an integrating factor for the local agents' involvement in education. Their connection to fund allocation is the foundation of their importance, yet they have too little real authority so they mainly serve as a basis for information storage and local communication stimulator. This is the basis the planner deals with when taking action in his position. Yet such a perspective forces us to rethink the goals we are associating with the whole of education system all together.

All in all, I can conclude that there are significant similarities in the education funding policy of the Baltic states and the countries share the same problems. A closer analysis of the issues that the local municipalities face when implementing school network optimization could help to solve these.

\section{References}

Alonso, J. D. \& Sánchez, A. (eds.) (2011), Reforming Education Finance in Transition Countries: Six Case Studies in Per Capita Financing Systems, Washington, D.C.: World Bank.

BISS (2011), 'Pētìjums Sorosa fonda - Latvija iniciatīvas „Pārmaiņu iespējas skolām” ietekmes novērtējums,' The Baltic Institute of Social Sciences: Soros FoundationLatvia. Retrieved from http://www.sfl.lv/upload_file/2011\%20gads/Parmainu_ skolas_ietekmes_novertejums.pdf [accessed October 2012]

Bokans, J. (1996), 'Education Reform,' in N. Muižnieks (ed.) Latvia: Human Development Report, Riga: United Nations Development Programme, pp. 64-82. 
Eurydice (2012), Teachers' and School Heads' Salaries and Allowances in Europe, 2011/12. Eurydice Report. Retrieved from http:/eacea.ec.europa.eu/education/ eurydice/documents/facts_and_figures/salaries.pdf [accessed October 2012]

Geske, A.; Grīnfelds, A.; Kangro, A. \& Kiseḷova R. (2010), Ko skolēni zina un prot - kompetence lasī̌sanā, matemātikā un dabaszinātnēs: Latvija OECD valstu Starptautiskajā skolēnu novērtēšanas programmā 2009, Rīga: Latvijas Universitāte.

Hazans, M. (2010), 'Teacher Pay, Class Size and Local Governments: Evidence from the Latvian Reform,' IZA Discussion Paper, no. 5291.

Heidmets, M.; Kangro, A.; Ruus, V.; Matulionis, A.V.; Loogma, K.; Zilinskaite, V. \& Autio, T. (2011), 'Education,' in M. Lauristin (ed.) Estonian Human Development Report 2010/2011: Baltic Way(s) of Human Development: Twenty Years On, Tallinn: Eesti Koostöö Kogu, pp. 96-114.

Herczyński, J. (2011), 'Student Basket Reform in Lithuania: Fine-Tuning Central and Local Financing of Education,' in J. D. Alonso \& A. Sanchez (eds.) Reforming Education Finance in Transition Countries. Six Case Studies in Per Capita Financing Systems, Washington, D.C.: World Bank, pp. 133-197.

Kaminskas, K. (2010), Structures of Education and Training Systems in Europe. Lithuania. 2009/10 Edition, Retrieved from: http://eacea.ec.europa.eu/education/ eurydice.../documents/eurybase/structures/041_LT_EN.pdf [accessed October 2012].

MoES (2009), 'Izglītības funkciju nodrošināšana pēc Administratīvi teritoriālās reformas un finansēšanas modeḷa „Nauda seko skolēnam” ieviešanas. Ieteikumi pašvaldībām un izglītības darba vadītājiem,' Ministry of Education and Science. Retrieved from http://izm.izm.gov.lv/upload_file/rokasgramata-nauda-sekoskolenam-001.pdf [accessed October 2012]

Levačić, R. (2011), 'Per Capita Financing of Education in Estonia,' in J. D. Alonso \& A. Sanchez (eds.) Reforming Education Finance in Transition Countries: Six Case Studies in Per Capita Financing Systems, Washington, D.C.: World Bank, pp. 33-100.

Ministry Regulations (2009a), Regulations No. 837 of the Cabinet of Ministers of the Republic of Latvia, Riga, 28 July 2009.

- (2009b), Regulations No. 1616 of the Cabinet of Ministers of the Republic of Latvia, Riga, 22 December 2009.

Shukauskaite, A. (2007), 'Examining Peripheries of Substantive Democracy in Lithuania from the Point of View of Teachers: Intended and Unintended Outcomes of the Financial Reform in Education,' in E. Stevick, B. Levinson (eds.) Reimagining Civic Education: How Diverse Societies Form Democratic Citizens, Lanham, MD: Rowman \& Littlefield Publishers, Inc., pp. 147-171. 